\title{
Returns to Workplace Training for Male and Female Employees and Implications for the Gender Wage gap: A Quantile Regression Analysis
}

\author{
Rossella Icardi* \\ University of Bath, Claverton Down, Bath, UK BA2 7AY, Great Britain
}

Received: 04 April 2020, Accepted: 16 October 2020

\begin{abstract}
Context: Existing studies have explored the association between workplace training and wages suggesting that training participation may have a positive association with wages. However, we still know very little about whether this association varies between men and women. Through its potential positive association with wages, training may balance wage differences between men and women. In addition, the gender wage gap varies across the wage distribution. Differences in the association between training participation and wages for men and women across the earnings spectrum may offer an explanation as to why the discrepancy in female/male earnings is larger at some point of the wage distribution compared to others.

Approach: Using data from the Programme for International Assessment of Adult Competencies (PIAAC) and unconditional quantile regression, this paper examines whether the association between workplace training and wages differs between men and women at different points of the wage distribution across 14 European countries. To partly control for endogeneity in training participation, detailed measures of cognitive skills have been included in the models.
\end{abstract}

Findings: Findings show gender differences in the association between training and wages across the wage distribution. In most countries, results indicate larger training coefficients for women than men at the lower end of the wage spectrum whereas they are larger for men

${ }^{*}$ Corresponding author: ri216@bath.ac.uk 
at the top. This pattern holds across most countries with the only exception of Liberal ones, where women benefit less than men across the entire wage spectrum.

Conclusions: The findings of this work reveal that distributional variations in returns to workplace training follow a similar pattern across industrialized countries, despite their different institutional settings. Moreover, differences in training coefficients of men and women at different parts of the wage distribution suggest that training could reduce gender wage differences among low earners and potentially widen the gap in wages among individuals at the top of the wage distribution.

Keywords: Vocational Education and Training, Gender Differences, Unconditional Quantile Regression, Cross-National Comparison

\section{Introduction}

A wide body of research has explored differences in workplace training participation by gender. Whilst earlier studies show that men are more likely to participate compared to women (Avis, 2018; Blundell et al., 1996; Evertsson, 2004; Pischke, 2001), more recent ones suggest that this long-lasting trend has reversed and, nowadays, females have higher chances to take part in training compared to their male counterparts (e.g. Dammrich et al., 2016; Dieckhoff \& Steiber, 2011; Jones et al., 2008; O’Halloran, 2008; Simpson \& Stroh, 2002). These findings raise questions about whether the job rewards often associated with workplace training participation are also gendered. In particular, existing studies have explored the association between workplace training and wages suggesting that training participation may have a positive association with wages (Arulampalam \& Booth, 2001; Blundell et al., 1999; Ehlert, 2017; Gerfin, 2004). However, we still know very little about whether the association between training and wages varies between men and women. One reason for this is that research on the topic is somewhat gendered. Although a substantial body of literature has been generated around the topic of workplace training returns, existing research has largely focused on the experience of males (e.g. Arulampalam et al., 2004; Arulampalan \& Booth, 2001; Gerfin, 2004). Hence, empirical evidence on whether also women benefit from participation in workplace training is lacking.

The study of differences in returns to workplace training between men and women has important implications for social inequalities, for example related to the difference in median pay between men and women, the so-called gender wage gap. While on the decline in many countries, the gap is a persistent feature of virtually every nation's labour market (Blau \& Kahn, 2003). Explaining this gap has attracted much attention and existing studies on the topic are numerous (see e.g., the international evidence in Blau \& Kahn, 1996, 2003). Nevertheless, scholars still debate its underlying causes. Furthermore, research on gender wage 
differences has identified that the gap varies significantly across the wage distribution. Yet, findings are inconclusive. Whilst some studies show a tendency for that to be higher at the top (Albrecht et al., 2003; Huffman, 2004), others found larger gaps at the bottom (Arulampalam et al., 2007; Christofides et al., 2013; Nicodemo, 2009). Differences in the association between training participation and wages for men and women across the earnings spectrum may offer an explanation as to why the discrepancy in female/male earnings is larger at some point of the wage distribution compared to others. Yet, whether the association between training and wages varies between men and women has been under-researched and, to date, no existing study explored whether it differs across the wage distribution. To the best of the author's knowledge, only Arulampalan et al. (2010) examined how workplace training returns vary along men's wage spectrum in ten European countries. The current study advances current research by considering also their female counterparts.

Cross-country comparative work concerned with gendered labour market behaviour has stressed that institutional settings have an influence on women's opportunities in the labour market (e.g. Dieckhoff \& Steiber, 2011; Grönlund \& Magnusson, 2016; Wozny \& Schneider, 2014). For example, literature on the gender gap in training participation indicates that it differs considerably across countries thus suggesting that country-specific institutional arrangements shape differences in participation between men and women (Dämmrich et al., 2016; Dieckhoff et al., 2007; Wozny \& Schneider, 2014). Similarly, they may explain gender differences in other labour market outcomes connected to training, such as wages. In this paper, the study of the distributional gender gap in training effects across countries is related to variations in welfare state regimes. To do that, we borrow from an approach that links gender-specific labour market outcomes to welfare state interventions (Mandel, 2012). Mandel (2012) analyses the extent to which family policies contribute to the economic gains of women and emphasizes that family policy should not be expected to uniformly benefit women of different classes. In fact, the mechanisms by which welfare state policies have been found to affect women's labour market attainments are by nature linked to their skills and position in the labour market. This perspective is extended in this paper to explain gender differences in training wage effects along the wage distribution in diverse contexts.

This article explores gender differences in the wage outcomes associated with training. Specifically, it addresses the following research questions: Do workplace training wage returns differ between men and women across the wage distribution? If so, do they vary across countries? The empirical evidence is drawn from 2012 data for 14 European countries from the Programme for International Assessment of Adult Competencies (PIAAC) and unconditional quantile regression (UQR). The interest of this study is to investigate training events that happen at the workplace, after labour market entry. The definition of training available in PIAAC data suggests that training refers to formal courses of instruction, rather than informal on-the-job training (Organisation for Economic Co-operation and Development 
[OECD], 2013). Given the cross-sectional nature of the PIAAC data, this analysis seeks to describe gendered patterns in the association between workplace training and wages and not to disentangle causal effects.

\section{A Gendered Approach in the Study of Workplace Training Returns}

An extensive literature has investigated the effect of training participation on wages, and offers evidence that training might improve the wages of those who participate, although results vary substantially across types of training and the related skills gained, as well as countries. Existing studies suggest that general skills training (e.g. to maintain occupational standards) is associated with higher productivity (Barret \& O'Connel, 2001) and wage returns (Jones et al., 2011; Luchinskaya \& Dickinson, 2019), while this is not the case for specific training (e.g. induction training). Research on soft skills (for instance, communication, cooperation) also indicates that these are associated with significant wage returns (for a review, see Balcar, 2014). In the UK, estimated returns to training range from 1\% (Booth, 1993) to $18 \%$ (Booth, 1991). Positive effects of training on wages are found for Norway (1\% increase; Schøne, 2004), Switzerland (2\%; Gerfin, 2004), and Portugal (3\%; Budria \& Pereira, 2007). The results for Germany are less clear, when confronting the finding of no return of Pischke (2001) and a 5\% increase of Mühler et al. (2007). Similarly, evidence is inconclusive in France (no return in Goux \& Maurin, 2000; positive return for job switchers in Fougère et al., 2001). Due to different concepts and definitions of training across countries and datasets, the comparability of results across countries is limited. A few studies circumvent some of these limitations by exploiting cross-country data (see OECD 1999, 2004). Bassanini et al. (2007) estimate a positive impact of training on earnings for most of the analysed countries; this return ranges from $3.7 \%$ for the Netherlands to $21.6 \%$ for Greece and is sensitive to the statistical method employed.

Although existing evidence suggests that training participation may improve individuals' wages, only a few studies have investigated whether this association varies by gender. Brunello (2001) and the OECD (2004) found lower wage returns to training for women, whereas some country studies found no difference, or even the opposite pattern (for a review, see Hansson, 2008). Triventi and Barone (2014) found that women, on the whole, benefit more than men from participation in adult learning activities. Through its positive association with wages, workplace training might have a role in reducing wage differences and may be a key policy intervention to tackle difference in wages between men and women. Research on the gender wage gap also indicates that it is not equal across groups, but it is largest among the highly educated (Evertsson et al., 2009), and in high-prestige occupations (Magnusson, 2010). Similarly, existing studies have shown that it is not constant across the wage distribution (Albrecht et al., 2003; Arulampalan et al., 2007; Christofides et al., 2013; Huffman, 2004; 
Nicodemo, 2009). These findings suggest that causes of gender inequality vary across individuals with different characteristics. Previous literature on the association between training participation and wages has mainly examined whether it exists on average. Yet, individuals have different capabilities to adapt to participation in training: some of them may exploit the skills acquired through training more than others thereby generating differences in the related wage effects.

Existing literature maintains that workplace training has a positive effect on wages for several reasons: first, from a human capital perspective, it provides specific skills that increase productivity and, in turn, wages (Becker, 1962); second, participation in learning is a signal of high motivation and job involvement (signalling approach, Spence, 1973), which is positively rewarded by employers. Finally, training participation provides certificates needed for promotion to higher ranked positions (credentialist approach, Collins, 1979) (for a review, see Minello \& Blossfeld, 2017). Despite widely used to explain differences in economic payoff deriving from training, these approaches have been challenged on several sides by other social science disciplines as well as by scholars within the same field of economics. For instance, feminist economists have taken the distance from this position (for a discussion, see England \& Folbre, 2003). In particular, economic perspectives have been criticised for their inability to properly account for the impact of skills on wage outcomes. Existing research has pointed out that the human capital perspective alone cannot explain wage differentials but it needs to be considered alongside other economic, social and institutional factors, such as collective agreements and awards (Oliver, 2016). Economic theories, moreover, do not offer a comprehensive framework to assess the impact of workplace training on wages of men and women. One major limitation has been their failure to explain or critique gender-based inequality and norms (Watts, 2003). Gender wage differences may, thus, be better explained by considering the presence of occupational segregation and statistical discrimination in the labour market.

Occupational segregation is understood as the different distribution of men and women across occupational categories and industries where women tend to be confined in lower paid jobs (Weeden \& Sørensen, 2004). Empirical studies have shown that occupational segregation is related to the gender wage gap (Dolado, 2003; England et al., 2007) and there is a common agreement in the literature that occupations with predominance of females suffer from a wage penalty (e.g. Perales, 2013) and slower wage growth (e.g. Olsen \& Walby, 2004). Lower remuneration in female-dominated occupations may also constrain the payoff consequent to workplace training participation. According to statistical discrimination (Arrow, 1973) instead, because information is costly to obtain, employers often rely on beliefs about group-level differences in factors related to productivity or other work-related traits. Due to gender-specific roles and family constraints, women tend to have more discontinuous careers than men; therefore, they are usually considered less attached to work and less productive. In 
contrast, men usually have more continuous participation in the labour market; this leads to greater investment in their working career. For the reasons deriving from both occupational segregation as well as discrimination, it seems plausible to expect women to experience lower rewards to training than men. In addition, these dynamics may differ across the earnings spectrum. Although Arrow's (1973) original formulation of statistical discrimination was assumed to apply equally to all workers, it is likely to be particularly detrimental for women with high human capital resources, who are likely to also have higher earnings potential and prestige. Existing research shows that the wage return to occupational prestige is higher for men than for women; for example, Magnusson (2009) finds that the gender difference in payoff to prestige is especially pronounced in the upper part of the prestige distribution, among high earners. The skewed division of family duties, in fact, makes it more difficult for women than men to have wage promoting job characteristics in high-prestigious occupations (Magnusson, 2010; Blair-Loy, 2003). This means that, even when women and men achieve similar occupational prestige, the payoff to prestige is higher for men (Magnusson, 2009).

Taken together, the outlined mechanisms indicate that women should benefit less from training and that the association between training and wages should vary between men and women along the wage distribution. Specifically, if we assume that statistical discrimination is more detrimental for women in highly prestigious (and highly paid) positions, we should expect women to benefit less than men at the top (Hypothesis 1).

\subsection{Cross-Country Variation in Gendered Returns to Workplace Training}

Comparative studies on gendered labour market behaviour have shown that institutional settings have an influence on women's opportunities in the labour market in several dimensions (e.g. Dieckhoff \& Steiber, 2011; Grönlund \& Magnusson, 2016; Wozny \& Schneider, 2014). For example, Wozny \& Schneider (2014) find that a system of vocational education and training (VET) and skills geared towards firm-specific skills enhances the female training gap. Similarly, institutional differences may affect gender differences in workplace training returns.

Overall, institutional regulations can affect the economic value of training via wage policies and collective bargaining. Centralised wage bargaining, for example, is aimed at reducing variation in wages (Badescu et al., 2011). It can, therefore, be expected that formal adult education is also associated with less income variation in these countries. Although a substantial number of existing studies confirm that wage-setting institutions affect the level of wage inequality overall (Blau \& Kahn, 1996, 2003; Mandel \& Semyonov, 2005), no comprehensive framework exists that assesses variations in the association between training and wages by gender across countries. In this paper, differences between men and women across the wage distribution are related to differences across welfare states interventions and family 
policies. This approach has been borrowed by Mandel (2012), who tackles the study of gender wage inequalities by offering new insights on how welfare states policies interact with socio-economic positions. Her argument is extended in this paper to motivate why gender differences in training rewards should vary across the wage distribution in different contexts. In her work, Mandel (2012) maintains that the impact of welfare state interventions on women's earnings and, in turn, on the gender wage gap is conditioned by class. For example, she suggests that extensive family policies which are aimed at favouring labour market reconciliation may also institutionalise work interruptions. While the latter favour low skilled women, they also increase statistical discrimination, which is likely to hurt highly educated and career oriented women the most. Or, similarly, centralised wage bargaining systems favour low earning women by reducing wage dispersion, because women are more likely than men to be low paid. However, centralised wage setting institutions are not of any interest to highly educated and high earning women, because these institutions compress wages; this may reduce the wages which these women may reach and, additionally, raise the cost of outsourcing domestic services. Following from this, it is plausible to expect high earning women to benefit less than high earning men from training participation in countries with more developed welfare systems (Hypothesis 2).

Based on the welfare regimes and Varieties of Capitalism classifications (Esping-Andersen, 1999; Hall \& Soskice, 2001), countries in this paper belong to four main groups. These classifications distinguish countries on the basis of the generosity of the welfare states and range from those who offer more extensive state policies, to those characterised by a minimal role of the state: 1 . Social Democratic (Norway, Denmark, Finland); 2. Conservatives and Central European (Belgium, France, Germany, the Netherlands); 3. Post-Socialists and Eastern European (Czech Republic, Slovak Republic, Poland); 4. Southern European (Italy, Spain); 5. Liberal (Ireland, the UK).

\section{Data, Sample and Empirical Strategy}

This paper uses data from the Programme of International Assessment of Adult Competencies (PIAAC). This dataset is particularly suitable for this analysis for two main reasons. First, it provides cross-national comparable information on workplace training and on a wide range of background characteristics. Second, it includes an assessment of cognitive skills in three domains: literacy, numeracy, and problem solving in technology-rich environments, which is rarely contained in existing social surveys (domains are described in OECD, 2013). The analysis is based on the year 2012 and on 14 countries (listed in Table 1). ${ }^{1}$ The sample includes individuals aged 18-65 who are in employment at the time of the survey. As wage regulations

1 Greece and Portugal are omitted due to gaps in the training data and because of the small estimating subsamples with usable information for those countries. 
and training opportunities for employed individuals are different from self-employed, the latter have been excluded. Also students and those in paid apprenticeship have been dropped to rule out training forms that are not work-related. Final sample sizes are reported in the last column of Table 1. The countries used different sampling schemes in drawing their samples, but these were all aligned to known population counts with post-sampling weightings. Analyses employ sample weights in the estimations throughout.

\subsection{Variables}

The dependent variable is hourly wages. This variable in PIAAC data is defined as hourly earnings excluding bonuses for wage and salary earners. ${ }^{2}$ Wage measures are used in its logarithmic form to interpret the results as estimated percent changes in hourly wages. As these are percentage effects, a similar coefficient across respondents' wage distribution would translate into larger absolute wage effects at higher points in the wage distribution.

The key independent variable is a measure of workplace training participation. Workplace training is defined as a training session organized in the workplace or provided by their supervisors or colleagues in the 12 months prior to the interview. According to the PIAAC definition, training sessions should be characterized "by planned periods of training, instruction or practical experience, using the normal methods of work" and include "training or instruction courses organized by the directors, managers or colleagues to help the respondent to do their job better or to familiarize them with their new tasks" (PIAAC survey questionnaire). The framing of the question suggests that the training responses should be interpreted as more formal courses of instruction, rather than informal on-the-job training (OECD, 2013).

Control variables have been chosen based on their likelihood to affect training returns and to vary by gender and are all coded according to standard, internationally comparable definitions. Education levels are defined according to UNESCO's International Standard Classification of Education (ISCED 1 to 6) ${ }^{3}$, and account for differences across individuals' background to participate and benefit from training and for gender differences in educational attainment (Blossfeld et al., 2016). Age is added in its linear and quadratic form to account for differences across the life course. To account for differences in employment characteristics, models include dummies for occupation, part-time and firm size. The data on occupation is defined using the International Standard Classification of Occupations (ISCO88) and it distinguishes between professional and managerial, clerks and technicians, machine and elementary workers. At last, information on skill levels is included; this information

2 In the PIAAC Public Use File, earnings data for Austria, Germany, and Sweden are reported only in deciles. Continuous wage information has been obtained from the German national data centre whereas it was not possible to obtain that from the other two countries which have been, therefore, excluded.

3 Respondents who obtained their highest educational qualification abroad are excluded because a high degree of measurement error on the educational attainment variable can be expected for these respondents (Schneider, 2018). 
is used to control for -usually unobserved- differences between training and non-training participants. The relevance of this variable will be discussed further in the next section.

\subsection{Analytical Strategy}

To estimate the association between training and wages at different quantiles of the wage distribution, this paper uses unconditional quantile regressions (UQR) (Firpo et al., 2009). Unlike the conditional version developed by Koenker and Bassett (1978), the main advantage of the UQR method is that it allows for an analysis of the effect of small changes in the distribution of the independent variables on the unconditional quantile of the dependent variable, not conditional on the covariates included in models. UQR involves calculating a recentered influence function (RIF) to create a transformed dependent variable that can then be analysed using ordinary least squares (OLS) regression. The use of OLS in the second step allows effects to be interpreted as the impact at the specified quantiles when some constant increase in $\mathrm{X}$ is added to everybody's value of $\mathrm{X}$, controlling for the other covariates (Firpo et al., 2009). In the case of a binary covariate (i.e. workplace training participation) the coefficient corresponds to a small increase in the probability of such covariate being equal to 1. Hence, the UQR coefficients of wages on training participation correspond to changes in the overall median wage caused by a small increase in the proportion of trained workers. The association between training participation and wages is estimated at the 10th, 25th, 50th, 75th, and 90th percentiles on a pooled sample of men and women. The model includes all the control variables listed above and an interaction term to explore whether the association between training and wages varies by gender.

\subsection{Further Empirical Considerations}

Selectivity and endogeneity bias are likely to affect the estimates of workplace training returns. The first refers to the different self-selection process within the group of men and women in the labour market while the second to the possibility of training and non-training participants to have different observed or unobserved characteristics. A few recent studies have attempted to account for sample selection when implementing quantile regression techniques (see e.g. Nicodemo, 2009). These studies have generally applied a semi-parametric adaptation of the Heckman parametric procedure for quantile wage regressions, as proposed by Buchinsky (1998). However, any selection correction within a quantile framework suffers from significant challenges, also with regard to the general issue of the validity of the instrument (to implement Heckman selection procedures). Hence, due to the lack of a good instrument in PIAAC data, this approach was excluded. 
In the literature on training returns, the issue of training endogeneity is well known (e.g. Luchinskaya \& Dickinson, 2019). The problem arises because training participation may not be random, but training participants may have different observed or unobserved characteristics compared to those who do not. In the absence of any corrections for the selection problem, estimated coefficients of the effect of training on wages are likely to be biased. Unconditional quantile regression does not take the presence of unobserved characteristics into consideration and this issue is likely to affect the estimates of this study. ${ }^{4}$ Given the cross-sectional nature of PIAAC, it is not possible to control for stable unobserved differences among individuals. However, PIAAC includes information on individuals' skills level, usually not available in existing social surveys. A variable on numeracy skills ${ }^{5}$ has been added with the aim to reduce the unobserved differences between those who participate in training and those who do not. This would increase the likelihood of the conditional independence assumption (CIA), which involves that participation in the program and the outcome are statistically independent for individuals with the same set of observable characteristics, to be satisfied. It is acknowledged that this approach does not overcome the problem of endogeneity, but it is a further step in that direction and it differentiates this work from previous studies. Unfortunately, despite the inclusion of a wide array of control variables as well as measures of skills level, the analyses performed in this paper do not fully account for unobserved differences between trained and untrained individuals; this does not permit any causal claims about the effect of training participation on wages. Moreover, unobserved characteristics (e.g. work norms) are also likely to be gender specific. This may affect the estimates for men and women differently. Dieckhoff et al. (2007) estimated separate models of training returns by gender and found -after accounting for selection - non-significant effects for both men and women. These results were valid for all the countries under analysis with the only exception of Germany. In the country, after correcting for selection, they still found a significant association between training and wages for men, but not for women. Although direct empirical investigations cannot be performed with PIAAC data, existing studies suggest that accounting for unobserved differences would reduce training estimates for both genders.

Another limitation of the analysis performed concerns the time when variables have been measured. Whilst all the variables were measured at the time of the interview, the variable on workplace training captures an event that occurred sometime during the past 12 months. Thus, it is uncertain whether the background characteristics were the same when that took place. This is particularly relevant with regard to the measures of skills level: if variables included to partially control for omitted factors are themselves affected by the variable of interest (i.e. training), we incur in the problem of proxy control (Angrist \& Pischke, 2009).

4 Training endogeneity within a quantile regression framework can be tackled using the quantile treatment effects (Angrist \& Pischke, 2009). However, this method relies on the use of instrumental variables and has been, therefore, excluded.

5 Drawing on Hanushek et al. (2013), this paper uses only information on numeracy skills, because of a higher comparability of numeracy skills across countries. Robustness checks have indicated no difference across measures of skills levels. Results available upon request. 
Analyses show that training participation positively affects numeracy levels; therefore, estimates of training are expected to be downward biased. ${ }^{6}$

Another issue concerns the definition and time of measurement of training. The measurement of training may affect its associated reward. The human capital literature distinguishes between general and specific training based on who finances participation. This distinction is commonly used in the literature (e.g. Kauffman, 2015; McMullin \& Kilpi-Jaconen, 2014). PIAAC contains detailed information on training financing. However, in PIAAC some respondents report that there are no costs involved in training participation presumably neglecting the costs borne by the employers. To correct for this, the variable has been recoded and the category "there were no costs" was incorporated to the employer financed category "yes, totally" (because costs borne by the employers are totally borne by them). After the recoding, the percentage of training financed by the employer adds to over $90 \%$. Hence, this variable does not have enough variation to be informative and to allow for a distinction between employer- and employee-financed training. Also, the impossibility to identify when training took place before the interview generates a high heterogeneity in the time span between the measurement of training events and the interview, which may hinder the observation of the real association between training and wages.

\section{$4 \quad$ Results}

Descriptive statistics on a breakdown of the hourly wage distribution of men and women at different quantiles are displayed in Table 1. The q90/q10 ratio is used as a measure of income inequality as it compares the wage of the richest 10 percent and the poorest 10 percent (a ratio of 2 indicates that the top 10 percent earns twice as much as the bottom 10 percent). Overall, results confirm the presence of wage differences by gender across all countries, with men earning on average as well as across wage quantiles more than women. The 90/10 ratio ranges from about 1.1 to 1.7 in all countries and it is generally higher for men, thus indicating that the wage distribution is wider among men compared to women.

Table 2 shows training incidence across countries and average wage levels by participation status and by gender. Overall, participation rates range between 40 and $60 \%$ for men as well as women in all countries, apart from France and Italy where participation is below $30 \%$. Figures reveal the presence of gender differences in wages when distinguishing between trained and untrained employees. On average, trainees earn more than those who have not received training ( $\mathrm{p}$-value of $\mathrm{t}$-test $<0.05$ ) across all countries, apart from men and women in Norway and women in the Slovak Republic.

6 Results available from the author upon request. 
Table 1: Breakdown of log of Hourly Wage, by Wage Quantiles and Gender

\begin{tabular}{|c|c|c|c|c|c|c|c|c|}
\hline Country & Gender & Mean & SD & 10th & 50th & 90th & q90/q10 & $\mathbf{N}$ \\
\hline \multirow[t]{2}{*}{$\mathrm{BE}$} & Female & 2.76 & 0.40 & 2.30 & 2.73 & 3.21 & 1.40 & 1,296 \\
\hline & Male & 2.82 & 0.39 & 2.40 & 2.77 & 3.30 & 1.38 & 1,315 \\
\hline \multirow[t]{2}{*}{$\mathrm{CZ}$} & Female & 4.59 & 0.48 & 4.09 & 4.61 & 5.05 & 1.23 & 1,163 \\
\hline & Male & 4.81 & 0.48 & 4.32 & 4.81 & 5.32 & 1.23 & 1,188 \\
\hline \multirow[t]{2}{*}{$\mathrm{DE}$} & Female & 5.16 & 0.34 & 4.80 & 5.16 & 5.52 & 1.15 & 1,992 \\
\hline & Male & 5.25 & 0.41 & 4.86 & 5.23 & 5.69 & 1.17 & 1,963 \\
\hline \multirow[t]{2}{*}{ FI } & Female & 2.71 & 0.34 & 2.34 & 2.68 & 3.14 & 1.34 & 1,458 \\
\hline & Male & 2.87 & 0.36 & 2.45 & 2.84 & 3.37 & 1.38 & 1,466 \\
\hline \multirow[t]{2}{*}{ FR } & Female & 2.45 & 0.40 & 2.05 & 2.39 & 2.96 & 1.44 & 1,782 \\
\hline & Male & 2.56 & 0.38 & 2.17 & 2.49 & 3.06 & 1.41 & 1,781 \\
\hline \multirow[t]{2}{*}{ GE } & Female & 2.54 & 0.49 & 1.95 & 2.54 & 3.14 & 1.61 & 1,396 \\
\hline & Male & 2.73 & 0.52 & 2.05 & 2.74 & 3.35 & 1.63 & 1,456 \\
\hline \multirow[t]{2}{*}{ IRE } & Female & 2.76 & 0.51 & 2.20 & 2.71 & 3.40 & 1.55 & 1,471 \\
\hline & Male & 2.85 & 0.54 & 2.25 & 2.79 & 3.53 & 1.57 & 1,146 \\
\hline \multirow[t]{2}{*}{ ITA } & Female & 2.33 & 0.46 & 1.75 & 2.27 & 2.86 & 1.63 & 888 \\
\hline & Male & 2.38 & 0.45 & 1.85 & 2.33 & 2.99 & 1.61 & 965 \\
\hline \multirow[t]{2}{*}{ NETH } & Female & 2.74 & 0.50 & 2.27 & 2.71 & 3.22 & 1.42 & 1,395 \\
\hline & Male & 2.84 & 0.51 & 2.29 & 2.82 & 3.38 & 1.48 & 1,399 \\
\hline \multirow[t]{2}{*}{ NO } & Female & 5.26 & 0.33 & 4.91 & 5.26 & 5.62 & 1.14 & 1,361 \\
\hline & Male & 5.41 & 0.41 & 4.97 & 5.38 & 5.88 & 1.18 & 1,405 \\
\hline \multirow[t]{2}{*}{ POL } & Female & 2.66 & 0.57 & 2.07 & 2.59 & 3.36 & 1.62 & 1,475 \\
\hline & Male & 2.75 & 0.56 & 2.09 & 2.69 & 3.47 & 1.66 & 1,919 \\
\hline \multirow[t]{2}{*}{ SLO } & Female & 1.59 & 0.50 & 1.24 & 1.47 & 2.12 & 1.70 & 649 \\
\hline & Male & 1.76 & 0.76 & 1.24 & 1.55 & 2.30 & 1.85 & 845 \\
\hline \multirow[t]{2}{*}{ ESP } & Female & 2.12 & 0.51 & 1.53 & 2.07 & 2.76 & 1.80 & 1,089 \\
\hline & Male & 2.27 & 0.53 & 1.71 & 2.18 & 2.90 & 1.69 & 1,187 \\
\hline \multirow[t]{2}{*}{ UK } & Female & 2.31 & 0.48 & 1.79 & 2.24 & 2.95 & 1.64 & 2,617 \\
\hline & Male & 2.49 & 0.52 & 1.86 & 2.45 & 3.14 & 1.69 & 1,841 \\
\hline
\end{tabular}

Note. Wages are measured in the countries' national currencies and transformed in logarithmic scale. 
Table 2: Mean log of Hourly Wages for Trained and Untrained Individuals, by Gender

\begin{tabular}{|c|c|c|c|c|}
\hline Country & Gender & $\begin{array}{c}\text { Training } \\
\text { Incidence (\%) }\end{array}$ & $\begin{array}{l}\text { Wage if } \\
\text { Untrained }\end{array}$ & $\begin{array}{l}\text { Wage if } \\
\text { Trained }\end{array}$ \\
\hline \multirow[t]{2}{*}{ BE } & Female & 40.49 & 2.69 & 2.85 \\
\hline & Male & 42.67 & 2.77 & 2.88 \\
\hline \multirow[t]{2}{*}{$\mathrm{CZ}$} & Female & 49.44 & 4.49 & 4.70 \\
\hline & Male & 58.98 & 4.76 & 4.85 \\
\hline \multirow[t]{2}{*}{ DE } & Female & 54.66 & 5.10 & 5.21 \\
\hline & Male & 50.99 & 5.20 & 5.29 \\
\hline \multirow[t]{2}{*}{ FI } & Female & 66.74 & 2.59 & 2.77 \\
\hline & Male & 58.13 & 2.77 & 2.94 \\
\hline \multirow[t]{2}{*}{ FR } & Female & 28.06 & 2.41 & 2.55 \\
\hline & Male & 25.78 & 2.54 & 2.62 \\
\hline \multirow[t]{2}{*}{ GE } & Female & 46.17 & 2.42 & 2.68 \\
\hline & Male & 48.39 & 2.59 & 2.87 \\
\hline \multirow[t]{2}{*}{ IRE } & Female & 47.11 & 2.65 & 2.89 \\
\hline & Male & 52.29 & 2.74 & 2.95 \\
\hline \multirow[t]{2}{*}{ ITA } & Female & 24.13 & 2.28 & 2.46 \\
\hline & Male & 23.50 & 2.35 & 2.47 \\
\hline \multirow[t]{2}{*}{ NETH } & Female & 59.08 & 2.68 & 2.79 \\
\hline & Male & 56.55 & 2.79 & 2.89 \\
\hline \multirow[t]{2}{*}{ NO } & Female & 40.24 & 5.25 & 5.27 \\
\hline & Male & 43.00 & 5.40 & 5.42 \\
\hline \multirow[t]{2}{*}{ POL } & Female & 38.96 & 2.55 & 2.83 \\
\hline & Male & 35.67 & 2.64 & 2.94 \\
\hline \multirow[t]{2}{*}{ SLO } & Female & 40.97 & 1.57 & 1.62 \\
\hline & Male & 42.63 & 1.71 & 1.81 \\
\hline \multirow[t]{2}{*}{ ESP } & Female & 43.97 & 2.00 & 2.28 \\
\hline & Male & 46.60 & 2.16 & 2.39 \\
\hline \multirow[t]{2}{*}{ UK } & Female & 54.34 & 2.24 & 2.37 \\
\hline & Male & 51.37 & 2.39 & 2.58 \\
\hline
\end{tabular}

Note. Wages are measured in the countries' national currencies and expressed in logarithmic scale.

Table 3 presents estimates of training participation along the hourly wage distribution for each country and includes the interaction term between training and male (full models available in Appendix Tables A1-A14). As described in the methods section, endogeneity is not fully tackled in these models; this may affect the size and significance of training estimates across quantiles. The analysis of gender differences in workplace training returns at different quantiles of the wage distribution provides a detailed picture on the association between 
training and wages. Results indicate a variation in size and significance of such association across the wage distribution, which would not be detected by an estimation at the mean. The direction of the association, however, differs across wage quantiles as well as countries.

The central argument of this paper is that the association between training and wages varies between men and women along the wage distribution, and that women are expected to benefit less than men particularly at the top (H1). In addition, Hypothesis 2 relates to differences across countries and suggests that high earning women gain lower benefits from training than men, especially in countries with developed welfare states, with policies aimed at helping reconciliation between work and family. Figure 1 shows UQR coefficients across countries (patterned bars indicated statistically significant differences) ${ }^{7}$. In most countries results show larger training coefficients for women than men at the lower end of the wage spectrum whereas they are larger for men at the top. In detail, the positive sign of the interaction at the upper tail suggests that men benefit from training more than women, thus supporting Hypothesis 1. However, it is worth noting that differences in coefficients of men and women reach statistical significance only in Denmark, Finland, Germany, Poland and the UK. Higher coefficients for men at the top of the wage distribution suggest that training participation may contribute to the widening of gender gap in wages among high earners. In contrast, at the lower end of the wage distribution, women show positive and significantly higher rewards compared to men. This finding indicates that participation in training and its rewards may reduce wage differentials between men and women at the lower end of the wage spectrum.

With regard to cross country variations, the second hypothesis of this paper suggests that high earning women should experience lower rewards from training compared to men especially in countries with developed welfare states. Results offer a partial support to this hypothesis. In the Social Democratic countries, women show smaller coefficients than men at the top and differences reach statistical significance at conventional levels (in Denmark and Finland, but not in Norway). These results partly fit the argument developed by Mandel (2012), who states that policy interventions aimed at reducing the gender wage gap affect women differently according to their socio-economic status. This argument would explain larger effects among women than men at the bottom, as they benefit from - for example higher employment protection and family friendly policies. In contrast, these same policies negatively affect highly educated and high earning women. Although this explanation seems plausible for Social Democratic countries, a similar pattern seems to hold across countries thus offering little support to this hypothesis. Countries belonging to the Liberal group, such as the UK and Ireland, offer an exception to this overall pattern. In the latter countries, women benefit less than men across the entire wage distribution (although differences do not reach statistical significance at the lower end). This may indicate the high level of inequality

7 Full tables of results are available from the author upon request. 
in such countries, at a disadvantage of women. In addition, it may reflect the scarcity of family policies that do not offer any support to working women.

Table 3: UQR Coefficients of Workplace Training on Wages, by Gender

\begin{tabular}{|c|c|c|c|c|c|c|}
\hline Country & & q10 & $\mathbf{q} 25$ & q50 & q75 & q90 \\
\hline \multirow[t]{4}{*}{ BE } & Training & $0.084^{* * *}$ & $0.127^{* * *}$ & $0.086^{* * *}$ & $0.056^{*}$ & 0.009 \\
\hline & & $(0.03)$ & $(0.02)$ & $(0.02)$ & $(0.03)$ & $(0.04)$ \\
\hline & Training*male & -0.025 & $-0.069^{* *}$ & -0.023 & -0.035 & -0.041 \\
\hline & & $(0.04)$ & $(0.03)$ & $(0.03)$ & $(0.04)$ & $(0.06)$ \\
\hline \multirow[t]{4}{*}{$\mathrm{CZ}$} & Training & $0.175^{\star *}$ & $0.111^{\star *}$ & $0.083^{* *}$ & 0.011 & 0.037 \\
\hline & & $(0.07)$ & $(0.05)$ & $(0.04)$ & $(0.04)$ & $(0.06)$ \\
\hline & Training ${ }^{\star}$ male & -0.032 & -0.022 & -0.024 & 0.028 & -0.117 \\
\hline & & $(0.09)$ & $(0.07)$ & $(0.06)$ & $(0.05)$ & $(0.10)$ \\
\hline \multirow[t]{4}{*}{ DE } & Training & $0.166^{* * *}$ & $0.084^{* * *}$ & $0.034^{* *}$ & $-0.033^{\star}$ & -0.017 \\
\hline & & $(0.03)$ & $(0.02)$ & $(0.02)$ & $(0.02)$ & $(0.03)$ \\
\hline & Training*male & $-0.084^{* *}$ & $-0.056^{\star *}$ & 0.019 & $0.082^{* * *}$ & 0.021 \\
\hline & & $(0.04)$ & $(0.03)$ & $(0.02)$ & $(0.03)$ & $(0.04)$ \\
\hline \multirow[t]{4}{*}{ FI } & Training & $0.142^{* * *}$ & $0.120^{\star * \star}$ & $0.047^{\star *}$ & -0.0019 & -0.021 \\
\hline & & $(0.03)$ & $(0.02)$ & $(0.02)$ & $(0.02)$ & $(0.03)$ \\
\hline & Training*male & $-0.079^{*}$ & $-0.066^{\star *}$ & 0.017 & $0.107^{\star * *}$ & $0.150^{* * *}$ \\
\hline & & $(0.04)$ & $(0.03)$ & $(0.03)$ & $(0.03)$ & $(0.05)$ \\
\hline \multirow[t]{4}{*}{ FR } & Training & $0.078^{* * *}$ & $0.051^{* * *}$ & $0.049^{* * *}$ & -0.019 & -0.057 \\
\hline & & $(0.03)$ & $(0.02)$ & $(0.02)$ & $(0.03)$ & $(0.05)$ \\
\hline & Training ${ }^{\star}$ male & $-0.086^{* *}$ & $-0.068^{* * *}$ & $-0.070^{* *}$ & 0.020 & 0.019 \\
\hline & & $(0.03)$ & $(0.02)$ & $(0.03)$ & $(0.04)$ & $(0.07)$ \\
\hline \multirow[t]{4}{*}{ GE } & Training & $0.266^{* * *}$ & $0.232^{\star * *}$ & $0.138^{* * *}$ & $0.076^{\star \star}$ & -0.010 \\
\hline & & $(0.05)$ & $(0.04)$ & $(0.03)$ & $(0.03)$ & $(0.03)$ \\
\hline & Training*male & $-0.125^{\star}$ & -0.051 & 0.015 & $0.078^{\star}$ & $0.143^{* * *}$ \\
\hline & & $(0.07)$ & $(0.05)$ & $(0.04)$ & $(0.04)$ & $(0.06)$ \\
\hline \multirow[t]{4}{*}{ IRE } & Training & $0.010^{* * *}$ & $0.154^{* * *}$ & $0.117^{* * *}$ & 0.046 & 0.002 \\
\hline & & $(0.03)$ & $(0.03)$ & $(0.03)$ & $(0.04)$ & $(0.05)$ \\
\hline & Training ${ }^{\star}$ male & -0.025 & -0.071 & 0.0002 & 0.062 & 0.044 \\
\hline & & $(0.04)$ & $(0.05)$ & $(0.05)$ & $(0.06)$ & $(0.08)$ \\
\hline \multirow[t]{4}{*}{ ITA } & Training & $0.160^{* * *}$ & $0.127^{* * *}$ & $0.149^{* * *}$ & 0.080 & 0.065 \\
\hline & & $(0.05)$ & $(0.04)$ & $(0.04)$ & $(0.06)$ & $(0.10)$ \\
\hline & Training ${ }^{\star}$ male & -0.058 & -0.013 & -0.056 & 0.052 & 0.066 \\
\hline & & $(0.07)$ & $(0.05)$ & $(0.05)$ & $(0.08)$ & $(0.15)$ \\
\hline \multirow[t]{3}{*}{ NETH } & Training & $0.106^{* * *}$ & $0.111^{* * *}$ & $0.083^{* * *}$ & -0.000 & $-0.095^{\star * *}$ \\
\hline & & $(0.04)$ & $(0.03)$ & $(0.02)$ & $(0.03)$ & $(0.04)$ \\
\hline & Training*male & -0.040 & $-0.089^{* *}$ & -0.052 & 0.045 & 0.087 \\
\hline
\end{tabular}




\begin{tabular}{|c|c|c|c|c|c|c|}
\hline Country & & q10 & q25 & q50 & q75 & q90 \\
\hline & & $(0.05)$ & $(0.04)$ & $(0.03)$ & $(0.04)$ & $(0.06)$ \\
\hline \multirow[t]{4}{*}{ NO } & Training & -0.004 & 0.015 & 0.017 & $0.053^{\star *}$ & 0.010 \\
\hline & & $(0.03)$ & $(0.02)$ & $(0.02)$ & $(0.02)$ & $(0.03)$ \\
\hline & Training ${ }^{\star}$ male & 0.029 & $0.044^{*}$ & 0.038 & -0.030 & 0.012 \\
\hline & & $(0.04)$ & $(0.03)$ & $(0.02)$ & $(0.04)$ & $(0.05)$ \\
\hline \multirow[t]{4}{*}{ POL } & Training & $0.109^{* * *}$ & $0.205^{\star * *}$ & $0.155^{* * *}$ & $0.118^{* *}$ & -0.068 \\
\hline & & $(0.03)$ & $(0.04)$ & $(0.04)$ & $(0.05)$ & $(0.08)$ \\
\hline & Training ${ }^{\star}$ male & -0.037 & $-0.104^{\star \star}$ & 0.052 & $0.119^{*}$ & $0.214^{\star *}$ \\
\hline & & $(0.04)$ & $(0.05)$ & $(0.06)$ & $(0.07)$ & $(0.11)$ \\
\hline \multirow[t]{4}{*}{ SLO } & Training & 0.004 & -0.020 & -0.025 & 0.035 & 0.146 \\
\hline & & $(0.02)$ & $(0.03)$ & $(0.03)$ & $(0.05)$ & $(0.11)$ \\
\hline & Training ${ }^{\star}$ male & 0.00238 & $0.0680^{*}$ & $0.0941^{\star \star}$ & 0.104 & 0.0648 \\
\hline & & $(0.03)$ & $(0.04)$ & $(0.04)$ & $(0.08)$ & $(0.16)$ \\
\hline \multirow[t]{4}{*}{ ESP } & Training & $0.173^{* * *}$ & $0.147^{* * *}$ & $0.098^{* * *}$ & $0.097^{\star *}$ & 0.006 \\
\hline & & $(0.04)$ & $(0.04)$ & $(0.03)$ & $(0.05)$ & $(0.06)$ \\
\hline & Training ${ }^{\star}$ male & $-0.116^{* *}$ & -0.040 & 0.037 & 0.102 & 0.098 \\
\hline & & $(0.05)$ & $(0.05)$ & $(0.05)$ & $(0.06)$ & $(0.08)$ \\
\hline \multirow[t]{4}{*}{ UK } & Training & 0.043 & $0.082^{* * *}$ & -0.010 & -0.041 & -0.051 \\
\hline & & $(0.03)$ & $(0.03)$ & $(0.03)$ & $(0.03)$ & $(0.04)$ \\
\hline & Training ${ }^{\star}$ male & 0.0128 & -0.002 & $0.097^{* *}$ & $0.137^{* *}$ & 0.103 \\
\hline & & $(0.04)$ & $(0.04)$ & $(0.05)$ & $(0.05)$ & $(0.08)$ \\
\hline
\end{tabular}

Note. ${ }^{*} \mathrm{p}<0.10,{ }^{* *} \mathrm{p}<0.05,{ }^{* * *} \mathrm{p}<0.01$ 

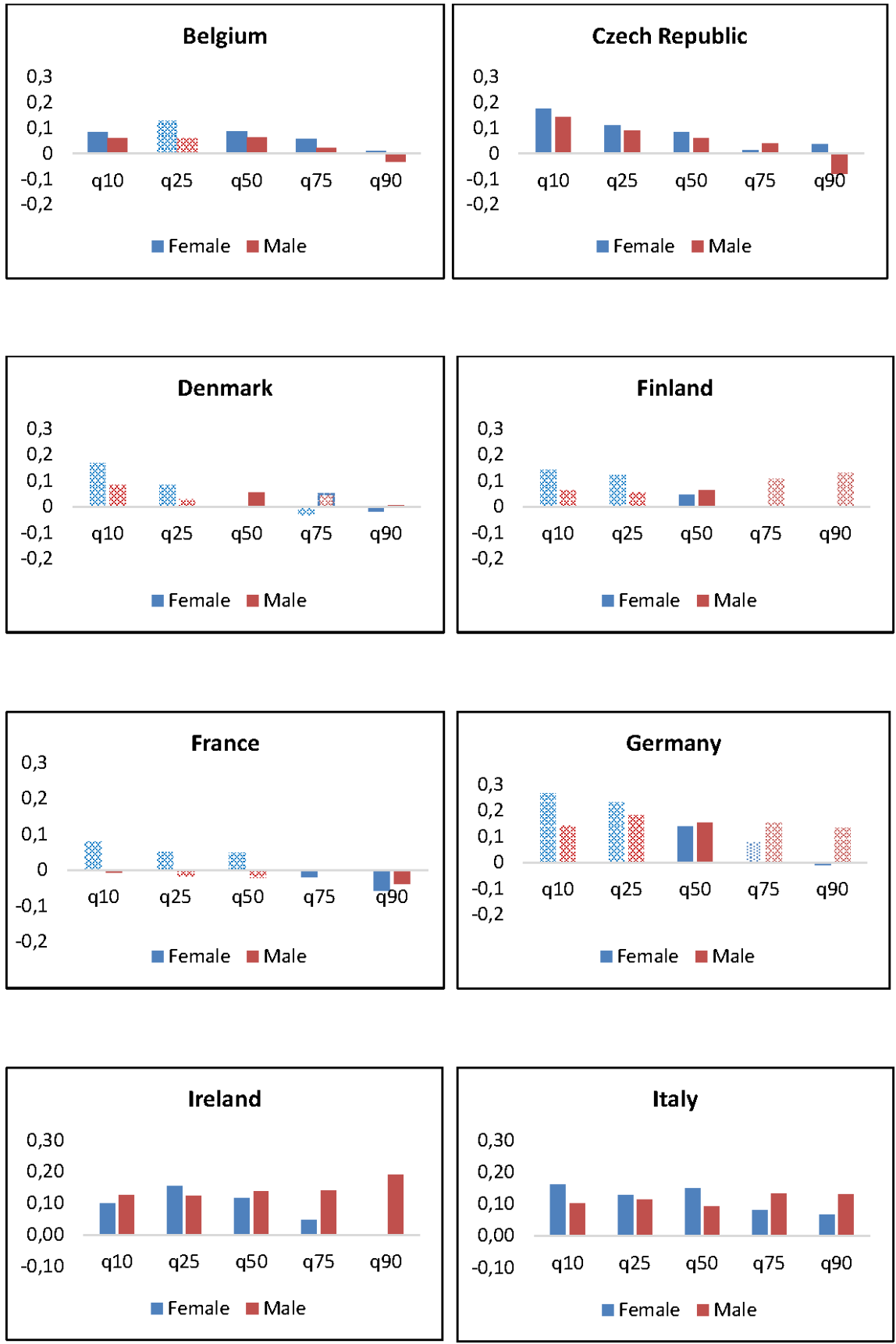

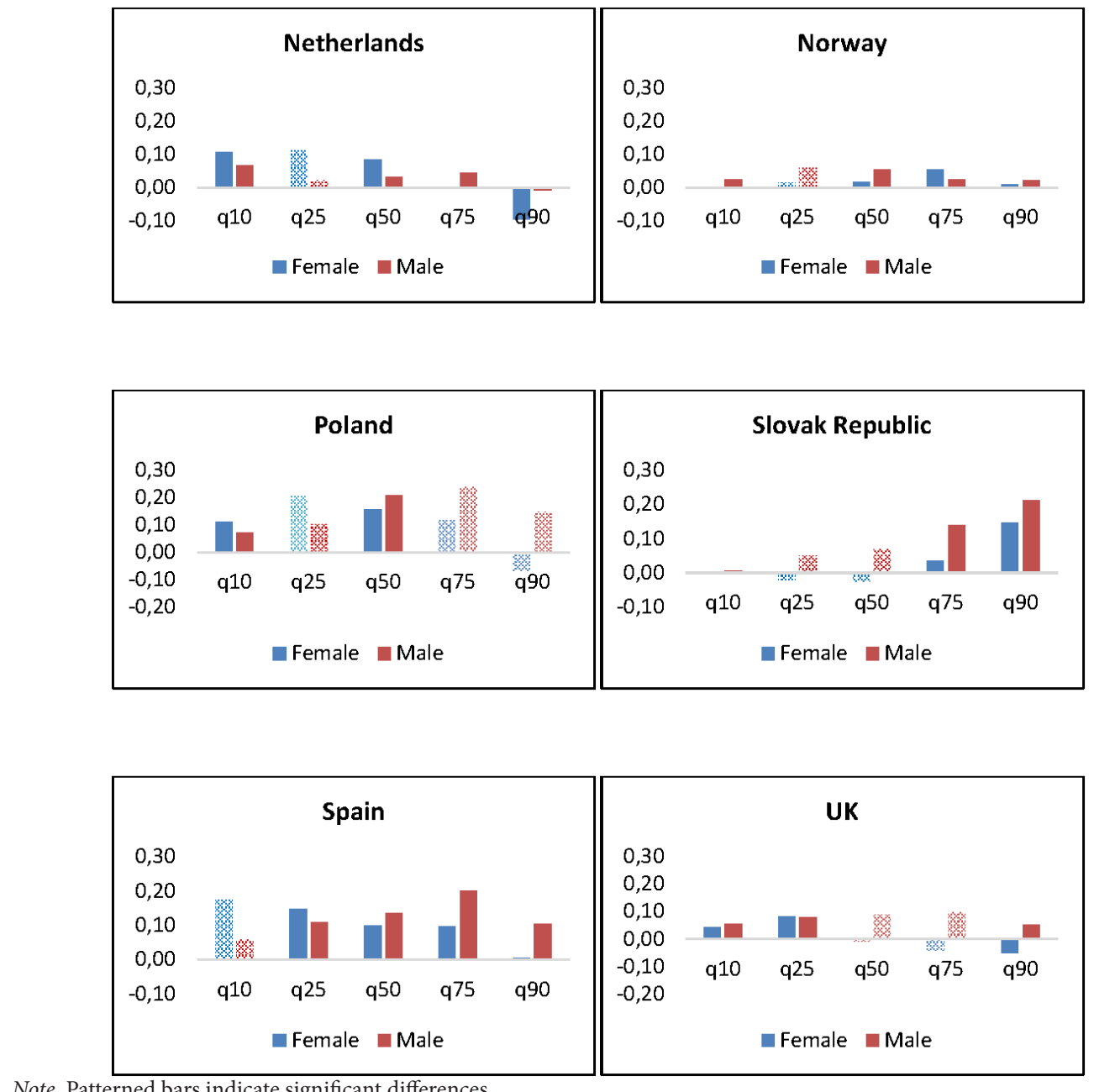

Note. Patterned bars indicate significant differences.

Figure 1: UQR Estimates of Training Participation on Wages, by Gender and Country

\section{Conclusions}

This paper has explored whether the association between workplace training and wages differs between men and women across the wage distribution. To date, research on gender differences in training rewards is scarce and, to the best of the author's knowledge, this is the first study to explore gendered patterns of training rewards within a quantile regression framework. Using comparative data from the PIAAC study, this article has extended the knowledge on gender differences in the wage effect of workplace training participation by investigating how they vary across the wage spectrum and across fourteen European countries. This paper assumed that women are rewarded less than men at the top of the wage distribution. 
Moreover, drawing from the study of Mandel (2012), it argued that extensive welfare state interventions have different effects on women labour market outcomes, based on their socioeconomic status.

In all, results confirm that a distributional approach provides further insights in the study of gender differences in training wage effects. Most countries display a statistically significant interaction effect between training and gender at different quantiles of the wage distribution, which would not be detected by an estimation at the mean. In detail, in most countries women have larger training coefficients than men at the lower end of the wage spectrum. This pattern is, however, opposite at the top of the wage distribution. This trend holds for all countries under observation, with the only exception of Liberal countries where women experience lower training benefits compared to men across the entire wage distribution. The finding of similar patterns across countries offers little support to the second hypothesis of this paper. The latter was drawn by considering the work of Mandel (2012), who maintains that the effect of welfare state interventions is conditioned by class, and that reconciliation policies are appropriate to all women in a similar manner. A second conclusion that can be drawn is that returns to workplace training for men and women follow a similar pattern across industrialized countries and that the institutional differences characterizing the four clusters of countries under examination are not fitted to describe them, at least with regard to returns to workplace training.

The results of this study have important policy implications. They show that women have larger training coefficients than men at the lower end of the wage spectrum whereas the size of coefficients is smaller at the top, among high earners. Overall, higher training effects for women at the lower end of the wage distribution across a considerable number of countries suggests that workplace training participation may lower the gap in wages between men and women in these contexts. Conversely, training may enlarge wage differences among high earners. There is an agreement in the literature that women invest more in training than men with regard to duration (O' Halloran, 2008) and financing (Burgard \& Görlitz, 2014). If this holds also in the countries under investigation, lower returns for high earning women indicate a disadvantage for them: despite investing more than men, women are not rewarded to the same extent as men are. The exploration of differences in individuals' investment in training (in terms of, e.g., time and money) between men and women could shed additional light on possible variations in training returns between them. The lack of reliable information on training investments has not allowed addressing the investigation within this work; however, it is a fruitful avenue for future research. Lower training returns for women at the top of the wage distribution suggest that participation in training may widen the gender wage gap among high earners. This may be the result of higher discrimination among those who reach high earning positions. Policies aimed at increasing gender equality encompass issues such as work flexibility and paid parental leave. However, these do not appear to have lessened the 
gender wage gap; rather, they may potentially exacerbate it if employers consequently avoid hiring women or reward them less due to costs incurred covering parental leave entitlements (Chang et al., 2014).

Overall, the findings of this study indicate that although workplace training participation has been argued to become increasingly necessary in order to reduce social inequalities (Kilpi-Jakonen et al., 2015), this may not be valid for all workers. Hence, current policy recommendations should not only focus on increasing participation rates but also pay greater attention to equality in terms of training outcomes. In fact, participation in training may not lead to a narrower gender wage gap if, as shown, women are rewarded less than men. To address this, policy debates should focus on new strategies to ensure that work of equivalent value is equally remunerated; this should happen regardless of the sex composition of the work force (Findlay et al., 2009). In relation to this latter point, exiting studies suggest that ad hoc responses to overcome gender segregation and attract more women into male-dominated trades should be developed in collaboration with a variety of actors involving industry, government and trade unions (Struthers \& Strachan, 2019).

This study also has some limitations, which need to be acknowledged. First, because of cross-sectional nature of PIAAC data, it is not possible to establish any causal interpretation of the empirical associations. Nevertheless, results are robust to the introduction of a rich set of controls relating to socio-demographic and occupational characteristics, as well as to a detailed measure of cognitive skills. Second, as the analysis of proxy control indicates, the estimates of workplace training reported in this study suffer from downward bias.

\section{References}

Albrecht, J., Bjorklund, A., \& Vroman, S. (2003). Is there a glass ceiling in Sweden? Journal of Labour Economics, 21(1), 145-177. https://doi.org/10.1086/344126

Angrist, J. D., \& Pischke, J. (2009). Mostly harmless econometrics: An empiricist's companion. Princeton University Press. https://doi.org/10.2307\%2Fj.ctvcm4j72

Arulampalan, W., \& Booth, A. (2001). Learning and earning: Do multiple training events pay? A decade of evidence from a cohort of young British men. Economica, 68(271), 379-400. https://doi. org/10.1111/1468-0335.00252

Arulampalam, W., Booth, A., \& Bryan, M. (2007). Is there a glass ceiling over Europe? Exploring the gender pay gap across the wages distribution. Industrial and Labor Relations Review, 60, 163-186. https://doi.org/10.1177/001979390706000201

Arulampalam, W., Booth, A., \& Bryan, M. (2010). Are there asymmetries in the effects of training on the conditional male wage distribution? Journal of Population Economics, 23(1), 251-272. https:// doi.org/10.1007/s00148-008-0209-4

Arrow, K. J. (1993). The theory of discrimination. In O. Ashenfelter \& A. Rees (Eds.), Discrimination in labor markets (pp. 1-33). Princeton University Press. https://doi.org/10.1515/9781400867066-003 
Avis, J. (2018). Crossing Boundaries: VET, the labour market and social justice. International Journal for Research in Vocational Education and Training, 5(3), 178-190. https://doi.org/10.13152/IJRVET.5.3.2

Badescu, M., D’Hombres, B., \& Villalba, E. (2011). Returns to education in European countries. Evidence from the European community statistics on income and living conditions. JRC scientific and technical reports. Publications Office of the European Union. https://core.ac.uk/download/ pdf/38621641.pdf

Balcar, J. (2014) Soft skills and their wage returns: Overview of empirical literature. Review of Economic Perspectives, 14(1), 3-15. https://doi.org/10.2478/revecp-2014-0001

Barrett, A., \& O'Connell, P. J. (2001). Does training generally work? The returns to in-company training. Industrial and Labor Relations Review, 54(3), 647-662. https://doi.org/10.1177/001979390 105400307

Bassanini, A., Booth, A., Brunello, G., De Paola, M., \& Leuven, E. (2007). Workplace training in Europe. In G. Brunello, P. Garibaldi \& E. Wasmer (Eds.), Education and training in Europe (pp. 8-13). Oxford University Press. https://doi.org/10.1093/acprof:oso/9780199210978.003.0009

Becker, G. S. (1962). Investment in human capital: A theoretical analysis. Journal of Political Economy, 70(5), 9-49. https://doi.org/10.1086/258724

Blair Loy, M. (2003). Competing devotions: Career and family among women executives. Journal of Marriage and Family, 67(3), 782-783. https://doi.org/10.1111/j.1741-3737.2005.00170.x

Blau, F., \& Kahn, L. (1996). Wage structure and gender earnings differentials: An international comparison. Economica, 63(250), 29-62. https://doi.org/10.2307/2554808

Blau, F., \& Kahn, L. (2003). Understanding international differences in the gender pay gap. Journal of Labor Economics, 21(1), 106-144. https://doi.org/10.3386/w8200

Booth, A. (1991). Job-related formal training: who receives it and what is it worth? Oxford Bullettin of Economics and Statistics, 53, 281-294. https://doi.org/10.1111/j.1468-0084.1991.mp53003004.x

Booth, A. (1993). Private sector training and graduate earnings. Review of Economics and Statistics, 75(1), 164-170. https://doi.org/10.2307/2109642

Blossfeld, P. N., Blossfeld, G. J., Blossfeld, H. P. (2016). Changes in educational inequality in crossnational perspective. In M. Shanahan, J. Mortimer \& M. Kirkpatrick Johnson (Eds.), Handbook of the life course. Handbooks of Sociology and Social Research (pp. 223-247). Springer. https://doi. org/10.1007/978-3-319-20880-0_10

Blundell, R., Dearden, L., \& Meghir, C. (1996). The determinants and effects of work related training in Britain. London Institute of Fiscal Studies. https://doi.org/10.1920/re.ifs.1996.0050

Blundell, R., Lorraine, D., Costas, M., \& Sianesi, B. (1999). Human capital investment: The returns from education and training to the individual, the firm and the economy. Fiscal Studies, 20(1), 1-23. https://doi.org/10.1111/j.1475-5890.1999.tb00001.x

Brunello, G. (2001). On the complementarity between education and training in Europe. SSRN Electronic Journal. https://doi.org/10.2139/ssrn.273040

Buchinsky, M. (1998). The dynamics of changes in the female wage distribution in the USA: A quantile regression approach. Journal of Applied Econometrics, 13(1), 1-30. https://doi.org/10.1002/ (sici)1099-1255(199801/02)13:1<1::aid-jae474>3.0.co;2-a

Budria, S., \& Pereira, P. T. (2007). The wage effects of training in Portugal: Differences across skill groups, genders, sectors and training types. Applied Economics, 39(6), 787-807. https://doi. org/10.1080/00036840500447757 
Burgard, C., \& Görlitz, K. (2014). Continuous training, job satisfaction and gender: An empirical analysis using German panel data. Evidence-based HRM, 2(2), 126-144. https://doi.org/10.2139/ ssrn. 1914239

Chang, J., Connell, J., Burgess, J., \& Travaglione, A. (2014). Gender wage gaps in Australian workplaces: Are policy responses working? Equality, Diversity and Inclusion, 33(8), 764-775. https://doi. org/10.1108/edi-10-2013-0080

Christofides, L. N., Polycarpou, A., \& Vrachimis, K. (2013). Gender wage gaps, "sticky floors" and "glass ceilings" in Europe. Labour Economics, 21, 86-102. https://doi.org/10.1016/j.labeco.2013.01.003

Collins, R. (1979). The credential society: An historical sociology of education and stratification. New York Academic Press.

Dämmrich, J., Kosyakova, Y., \& Blossfeld, H. P. (2016). Gender and job-related non-formal training: A comparison of 20 countries. International Journal of Comparative Sociology, 56(6), 433-459. https://doi.org/10.1177/0020715215626769

Dieckhoff, M., Jungblut, J. M., \& O'Connell, P. (2007). Job-related training in Europe: Do institutions matter? In D. Gallie (Ed.), Employment regimes and the quality of work (pp. 77-103). Oxford University Press.

Dieckhoff, M. \& Steiber, N. (2011). A re-assessment of common theoretical approaches to explain gender differences in continuing training participation. British Journal of Industrial Relations, 49, 135-157. https://doi.org/10.1111/j.1467-8543.2010.00824.x

Dolado, J., Felgueroso, F., \& Jimeno, J. F. (2003). Where do women work? Analysing patterns in occupational segregation by gender. Annales d'Economie et Statistique, 71/72, 267-292. https://doi. org/10.2307/20079056

Ehlert, M. (2017). Who benefits from training courses in Germany? Monetary returns to non-formal further education on a segmented labour market. European Sociological Review, 33(3), 436-448. https://doi.org/10.1093/esr/jcx042

England, P., Allison, P., \& Wu, X. (2007). Does bad pay cause occupations to feminize, does feminization reduce pay, and how can we tell with longitudinal data? Social Science Research, 36, 1237-1256. https://doi.org/10.1016/j.ssresearch.2006.08.003

England, P., \& Folbre, N. (2003). Contracting for care. In M. A. Ferber \& J. A. Nelson (Eds.), Feminist economics today: Beyond economic man (pp. 61-80). University of Chicago Press. https://press. uchicago.edu/ucp/books/book/chicago/F/bo3621956.html

Esping-Andersen, G. (1999). Social foundations of postindustrial economies. Oxford University Press.

Evertsson, M. (2004). Formal on-the-job training: A gender-typed experience and wage-related advantage? European Sociological Review, 20(1), 79-94. https://doi.org/10.1093/esr/20.1.79

Evertsson, M., England, P., Mooi-Reci, I., Hermsen, J., de Bruijn, J., \& Cotter, J. (2009). Is gender inequality greater at lower or higher educational levels? Common patterns in the Netherlands, Sweden, and the United States. Social Politics: International Studies in Gender, State \& Society, 16(2), 210-241. https://doi.org/10.1093/sp/jxp008

Findlay, P., Findlay, J., \& Stewart, R. (2009). The consequences of caring: Skills, regulation and reward among early years workers. Work, Employment and Society, 23(3), 422-441. https://doi. org/10.1177/0950017009337057

Firpo, S., Fortin, N. M., \& Lemieux, T. (2009). Unconditional quantile regressions. Econometrica, 77(3), 953-973. https://doi.org/10.3386/t0339 
Fougère, D., Goux, D., \& Maurin, E. (2001). Formation continue et carrières salariales. Une évaluation sur données individuelles. Annales d'Économie et de Statistique, 62, 49-69. https://doi. org $/ 10.2307 / 20076281$

Gerfin, M. (2004). Work-related training and wages: An empirical analysis for male workers in Switzerland. IZA Discussion Paper No. 1078. http://repec.iza.org/dp1078.pdf

Goux, D., \& Maurin, E. (2000). Returns to firm-provided training: Evidence from French worker-firm matched data. Labour Economics, 7(1), 1-19. https://doi.org/10.1016/s0927-5371(99)00023-8

Grönlund, A., \& Magnusson, C. (2016). Family-friendly policies and women's wages - is there a tradeoff? Skill investments, occupational segregation and the gender pay gap in Germany, Sweden and the UK. European Societies, 18(1), 91-113. https://doi.org/10.1080/14616696.2015.1124904

Hall, P. A., \& Soskice, D. (2001). Varieties of Capitalism: The institutional foundations of comparative advantage. Oxford University Press.

Hansson, B. (2008). Job-related training and benefits for individuals: A review of evidence and explanations, OECD Education Working Papers No. 19, OECD Publishing. https://doi.org/10.2139/ ssrn. 1347622

Hanushek, E. A., Schwerdt, G., Woessmann, L., \& Wiederhold, S. (2013). Returns to skills around the world: Evidence from Piaac. OECD Education Working Paper No. 101, OECD Publishing. https:// doi.org/10.3386/w19762

Huffman, M. L. (2004). Gender inequality across local wage hierarchies. Work and Occupations, 31(3), 323-344. https://doi.org/10.1177/0730888404266384

Jones, M. K., Jones, R. J., Latreille, P. L., \& Sloane, P. J. (2008). Training, job satisfaction and workplace performance in Britain: Evidence from WERS 2004. Labour, 23, 139-175. https://doi.org/10.1111/ j.1467-9914.2008.00434.x

Jones, D. C., Kalmi, P., \& Kauhanen, A. (2011). The effects of general and firm-specific training on wages and performance: Evidence from banking. Oxford Economic Papers, 64(1), 151-175. https:// doi.org/10.1093/oep/gpr013

Kauffman, K. (2015). Non-formal education in international comparison: Patterns of participation and investment in selected European countries. International Journal for Research in Vocational Education and Training, 2(4), 239-267. https://doi.org/10.13152/ijrvet.2.4.1

Kilpi-Jakonen, E., Vono de Vilhena, D., \& Blossfeld, H. (2015). Adult learning and social inequalities: Processes of equalisation or cumulative disadvantage? International Review of Education, 61, 529-546. https://doi.org/10.1007/s11159-015-9498-5

Koenker, R., \& Bassett, G. S. (1978). Regression quantiles. Econometrica, 46(1), 33-50. https://doi. org $/ 10.2307 / 1913643$

Luchinskaya, D., \& Dickinson, P. (2019). "Virtuous" and "Vicious" circles? Adults' participation in different types of training in the UK and its association with wages. Social Inclusion, 7(3), 177-201. https://doi.org/10.17645/si.v7i3.2039

Magnusson, C. (2009). Gender, occupational prestige and wages: A test of devaluation theory. European Sociological Review, 25, 87-101. https://doi.org/10.1093/esr/jcn035

Magnusson, C. (2010). Why is there a gender wage gap according to occupational prestige? Acta Sociologica, 53(2), 99-117. https://doi.org/10.1177/0001699310365627

Mandel, H. (2010). Winners and losers: The consequences of welfare state policies for gender wage inequality. European Sociological Review, 28(2), 241-262. https://doi.org/10.1093/esr/jcq061 
Mandel, H., \& Semyonov, M. (2006). A welfare state paradox: State interventions and women's employment opportunities in 22 countries. American Journal of Sociology, 111(6), 1910-1949. https:// doi.org/10.1086/499912

McMullin, P., \& Kilpi-Jakonen, E. (2014). Cumulative (dis)advantage? Patterns of participation and outcomes of adult learning in Great Britain. In H.-P. Blossfeld, E. Kilpi-Jakonen, D. Vono de Vilhena \& S. Buchholz (Eds.), Adult Learning in Modern Societies: An international comparison from a life-course perspective (pp. 119-139). Edward Elgar. https://doi.org/10.4337/9781783475186.00015

Minello, A., \& Blossfeld, H. P. (2017). Can adult education compensate for early disadvantages? The role of adult education in reducing inequalities for German men and women. In J. Erola \& E. Kilpi-Jakonen (Eds.), Social inequality across the generations: The role of compensation and multiplication in resource accumulation (pp. 161-180). Edward Elgar Publishing. https://doi. org/10.4337/9781786432568

Mühler, G., Beckmann, M., \& Schauenberg, B. (2007). The returns to continuous training in Germany: New evidence from propensity score matching estimators. Review of Managerial Science, 1, 209-235. https://doi.org/10.1007/s11846-007-0014-6

Nicodemo, C. (2009). Gender pay gap and quantile regression in European families. Iza Discussion Paper No. 3978. http://ftp.iza.org/dp3978.pdf

Organisation for Economic Co-operation and Development. (1999). Training of adult workers in OECD countries: Measurement and analysis. Employment Outlook, Chapter 3, OECD, Paris.

Organisation for Economic Co-operation and Development. (2004). Improving skills for more and better jobs: Does training make a difference? Employment outlook, Chapter 4, OECD, Paris.

Organisation for Economic Co-operation and Development. (2013). Technical report of the survey of adult skills (PIAAC), OECD, Paris.

O'Halloran, P. L. (2008). Gender differences in formal on-the-job training: Incidence, duration, and intensity. Labour, 22(4), 629-659. https://doi.org/10.1111/j.1467-9914.2008.00427.x

Oliver, D. (2016). Wage determination in Australia: The impact of qualifications, awards and enterprise agreements. JournalofIndustrialRelations, 58(1),69-92.https://doi.org/10.1177/0022185615598188

Olsen, W., \& Walby, S. (2004). Modelling gender pay gaps. Equal Opportunities Commission Working Paper Series no. 17. https://www.escholar.manchester.ac.uk/api/datastream?publicationPid=uk-acman-scw:75228\&datastreamId=FULL-TEXT.PDF

Perales, F. (2013). Occupational sex-segregation, specialized human capital and wages: Evidence from Britain. Work Employment \& Society, 27(4), 600-620. https://doi.org/10.1177/0950017012460305

Pischke, J. S. (2001). Continuous training in Germany. Journal of Population Economics, 14, 523-548. https://doi.org/10.1007/s001480000040

Schøne, P. (2004). Firm-financed training: Firm specific or general skills? Empirical Economics, 29, 885-900. https://doi.org/10.1007/s00181-004-0219-3

Schneider, S. L. (2018) Education in OECD’s PIAAC Study: How well do different harmonized measures predict skills? Methods, Data, Analysis, 12(1), 151-176. https://doi.org/10.12758/mda.2017.15

Simpson, P. A., \& Stroh, L. K. (2002). Revisiting gender variation in training. Feminist Economics, 8(3), 21-53. https://doi.org/10.1080/0003684022000026656

Spence, A. M. (1973). Job market signalling. Quarterly Journal of Economics, 87, 355-74. https://doi. $\operatorname{org} / 10.2307 / 1882010$ 
Struthers, K., \& Strachan, G. (2019). Attracting women into male-dominated trades: Views of young women in Australia. International Journal for Research in Vocational Education and Training, 6(1), 1-19. https://doi.org/10.13152/ijrvet.6.1.1

Triventi, M., \& Barone, C. (2014). Returns to adult learning in comparative perspective. In H.-P. Blossfeld, E. Kilpi-Jakonen, D. V. de Vilbena \& S. Buchholz (Eds.), Adult learning in modern societies: An international comparison from a life-course perspective (pp. 56-75). Edward Elgar. https:// doi.org/10.4337/9781783475186.00011

Watts, M. J. (2003). The evolution of occupational gender segregation in Australia: Measurement and interpretation. Australian Journal of Labour Economics, 6, 631-655. https://EconPapers.repec.org/ RePEc:ozl:journl:v:6:y:2003:i:4:p:631-655

Weeden, K. A., \& Sørensen, J. B. (2004). A framework for analyzing industrial and occupational sex segregation in the U.S.. Standford University Press.

Wozny, C., \& Schneider, M. R. (2014). A matter of degree: The continuing training gap for women in Europe. Socio-Economic Review, 12(2), 353-379. https://doi.org/10.1093/ser/mwu008

\section{Biographical Note}

Rossella Icardi is a Research Associate in the department of Social \& Policy Sciences at the University of Bath. Her main research interests include labour market outcomes of educational qualifications and comparative research. 